\title{
Analisa Decision Tree untuk Kepuasan Penggunaan Sinyal dari Base Transceiver Station (BTS)
}

\author{
Sasa Ani Arnomo ${ }^{\mathrm{a}}$ \\ ${ }^{a}$ Program Studi Sistem Informasi, Universitas Putera Batam \\ Jl. R. Soeprapto, Tembesi, Batam, Kepulauan Riau, Indonesia \\ ${ }^{1}$ sasa@puterabatam.ac.id
}

\begin{abstract}
Abstrak
Kepuasan konsumen merupakan salah satu tujuan perusahaan dalam memberikan pelayanan kepada konsumen baik perusahaan jasa maupun non jasa. Salah satu perusahaan penyedia layanan akses data internet yang berkomitmen untuk meningkatkan kualitas produk, fasilitas dan kualitas layanan demi kepuasan pelanggan. Penelitian ini bertujuan untuk menganalisis kepuasan konsumen dengan menggunakan metode algoritma data mining process metode C4.5 dan mengukur tingkat kepuasan konsumen dari hasil pohon keputusan yang diperoleh. Variabel penilaian meliputi kualitas produk, fasilitas, pelayanan dan harga dengan hasil keputusan puas atau tidak puas. Hasil pengolahan metode data mining menggunakan algoritma C4.5 mampu mengklasifikasikan tingkat kepuasan konsumen. Terbukti dengan tingkat akurasi $84.66 \%$, recall mendapatkan 0.828 , precision memperoleh 0.828 , dan ROC mendapat nilai 0.825 . Hasil penelitian ini dapat dijadikan acuan untuk meningkatkan kepuasan konsumen dan menjaga loyalitas konsumen dalam menggunakan produk paket data layanan internet dan meningkatkan penjualan.
\end{abstract}

Kata kunci: Data Mining, Decision Tree, BTS

\section{Decision Tree Analysis for Signal Use at Base Transceiver Station (BTS)}

\begin{abstract}
Consumer satisfaction is one of the goals of the company in providing services to consumers both service and nonservice companies. One of the internet data access service provider companies that is committed to improving product quality, facilities and service quality to customer satisfaction. This study aims to analyse the satisfaction consumers by using the data mining process $\mathrm{C} 4.5$ algorithm method and measure the level of customer satisfaction from the decision tree results obtained. The assessment variables include product quality, facilities, services and prices with the results of the decision satisfied or not satisfied. The results of processing data mining methods using the $\mathrm{C} 4.5$ algorithm were able to classify the level of customer satisfaction. It is proven by the accuracy rate of $84.66 \%$, the classification recall is 0.828 , the classification precision is 0.828 , and the ROC is 0.825 . The results of this study can be used as a reference to improve consumer satisfaction and to maintain customer loyalty in using internet service data package products and increasing sales.
\end{abstract}

Keywords: Data Mining, Decision Tree, BTS

\section{Pendahuluan}

Internet bukanlah hal yang asing di era obalisasi sekarang ini. Perkembangan teknologi komunikasi dan informasi yang pesat, menjadikan internet sebagai salah satu kebutuhan pokok baik bisnis[1] atau kebutuhan informasi masyarakat. Internet di masyarakat tentu tidak bisa berdiri dengan sendirinya, diperlukan dukungan dari perusahaan Internet Service Provider (ISP), sebagai penyedia sarana dan prasarana pendukung akses internet. Pada umumnya ISP memberikan layanan data akses internet pita lebar/broadbrand nirkabel yang menggunakan teknologi berbasis $4 G$ LTE dengan bantuan perangkat penghubung gelombang komunikasi Base Transceiver Station (BTS). BTS mulai banyak diperkotaan mengikuti meluasnya pengguna perangkat mobile[2][3] dan ecommerce[4].

Keberadaan BTS sangat terbatas walaupun sebenarnya banyak pengembangan daya[5][6][7] dan strategi bagaimanana mengefisienkan dayanya[8]. BTS menyediakan pengguna layanan akses data internet masih terbatas yaitu masyarakat yang hanya berada tidak lebih dari 100meter dari lokasinya. Sebagai penyedia layanan akses data internet maka ISP yang menggunakan BTS mendapat tekanan kompetisi, ketersediaan sarana dan prasarana serta jaringan. Hal tersebut karena memiliki 
tingkat daya saing yang tinggi dalam memenangi persaingan pasar industri telekomunikasi. Kondisi semacam ini memaksa penyedia layanan akses data internet untuk melakukan strategi yang tepat untuk meningkatkan serta mempertahankan produk layanan akses data internet di pasaran.

Base Transceiver Station (BTS) adalah infrastruktur utama yang menghubungkan pelanggan dengan jaringan seluler[9]. Dengan banyaknya penyedia layanan akses data internet yang sudah mendapatkan branding untuk mengenal seperti apa kelebihan ataupun kekurangan produknya di pasaran, terlebih adanya keluhan dari konsumen dan juga adanya konsumen yang beralih ke provider lain. Masalah keluhan dari konsumen di antaranya, kualitas layanan jaringan seperti sinyal yang terkadang bermasalah, kecepatan internet yang lambat, fasilitas customer service yang kurang memadai, serta kualitas pelayanan yang kurang responsif. Oleh karenanya, perlu dilakukan riset mengenai kepuasan konsumen untuk mempertahankan pengguna layanan akses data internet bahkan untuk meningkatkan pengguna layanan akses data internet di suatu wilayah.

Ketika konsumen tidak mendapatkan seperti apa yang diharapkan maka konsumen dinyatakan ketidakpuasan tidak tercapai. Sebaliknya ketika konsumen memperoleh apa yang diharapkan dari pelayanan yang ditawarkan maka konsumen dinyatakan kepuasan tercapai[10]. Terdapat beberapa point penting yang ada dalam kepuasan konsumen yaitu kualitas produk, harga, kualitas jasa dan emosi (emotional factor) [11]. Produk adalah segala sesuatu yang dapat ditawarkan perusahaan ke pasar untuk diamati, disukai, dan dibeli sehingga dapat memuaskan keinginan dan kebutuhan konsumen [12]. Produk dalam Penelitian ini adalah penyedia jasa internet. Semua konsumen menginginkan produk yang tidak hanya murah, namun juga berkualitas. Dengan menciptakan produk yang berkualitas, perusahaan akan memperoleh kepercayaan serta menciptakan kepuasan konsumen [13]. Kualitas pelayanan merupakan tingkatan kondisi baik buruknya sajian yang diberikan oleh perusahaan / penyedia jasa layanan. Dengan meningkatkan kualitas layanan maka konsumen akan memiliki sikap loyalitas terhadap produk yang digunakan [14]. Fasilitas dapat berupa segala sesuatu yang memudahkan konsumen dalam memperoleh kepuasan [15]. Fasilitas yang diberikan berupa pilihan paket data kepada konsumen. Harga juga seringkali dijadikan sebagai bahan pertimbangan bagi konsumen dalam melakukan pembelian [16].

Berdasarkan masalah di atas penelitian kepuasan konsumen tersebut akan dianalisis menggunakan pendekatan data mining dengan algoritma C4.5 untuk menentukan pola kepuasan konsumen. Data mining atau disebut juga sebagai penambangan data yang berguna untuk menemukan pola atau relasi antar data secara otomatis. Dengan menggunakan metode pohon keputusan algoritma $\mathrm{C} 4.5$ yang bisa menampilkan hasil perhitungan berupa pohon keputusan yang sangat mudah dipahami dan dimengerti, yang mana nantinya akan ditampilkan adalah tingkat kepuasan atau ketidakpuasan yang dirasakan oleh konsumen. Sehingga hal tersebut bisa memberikan gambaran kepada pimpinan perusahaan untuk bisa membuat strategi ke depannya baik untuk mempertahankan konsumen atau pun menambah jumlah konsumen pengguna layanan akses data internet. Untuk memenuhi kebutuhan-kebutuhan di atas, banyak cara yang dapat ditempuh. Salah satunya adalah menggunakan kuesioner online dengan memberikan seperangkat pertanyaan yang telah disediakan pilihan jawaban untuk dipilih oleh objek penelitian dengan menggunakan beberapa indikator yaitu, kualitas produk, fasilitas, pelayanan, dan harga.

\section{MetodoloGi}

Data yang digunakan dalam penelitian ini yaitu nomor urutan genap yang ada dalam data populasi dan hanya menggunakan data konsumen dengan nomor telepon yang aktif. Dari 131 konsumen yang ada dalam data populasi didapatkan sebanyak 65 konsumen yang berada dalam urutan nomor genap. Dan dari 65 konsumen yang terpilih dalam urutan genap hanya 47 konsumen dengan nomor telepon aktif.

\section{A. Metode Analisa}

Data mining juga dikatakan knowledge discovery in database (KDD) membentuk aktivitas dengan cakupan pengumpulan, pemakaian, historis yang akan menghasilkan kesesuaian, pola atau hubungan pada set data yang berukuran besar [17]. Knowledge Discovery in Database (KDD) merupakan teknik atau cara pencarian yang mengimplikasikan pelaksanaan berbagai metode algoritma guna memanipulasi data, membentuk model dari data, juga memanipulasi model[18].

\section{B. Algoritma C4.5}

Pada penggunan algoritma C4.5 terlihat berbagai tahapan yaitu pengubahan bentuk data pada tabel menjadi model pohon kemudian pengubahan model pohon menjadi aturan (rule) dan terakhir penyederhanaan rule. Secara umum, algoritma C4.5 untuk membangun pohon keputusan adalah sebagai berikut:

1. Mengihitung jumlah data

2. Memilih atribut sebagai Node

3. Membuat cabang untuk tiap-tiap anggota dari Node

4. Periksa apakah nilai entropy dari anggota node ada yang bernilai nol. Jika ada, tentukan daun yang terbentuk. Jika seluruh nilai entropy anggota node adalah nol, maka proses pun dihentikan.

5. Jika ada anggota node yang memiliki nilai entropy lebih besar dari nol, ulangi lagi proses dari awal dengan node sebagai syarat sampai semua anggota dari node bernilai nol.

Untuk melakukan perhitungan nilai gain suatu atribut menggunakan rumus seperti yang tertera dalam persamaan berikut [19]:

$\operatorname{Gain}(\mathrm{S}, \mathrm{A})=\operatorname{Entropy}(s)-\sum_{i=1}^{n} \frac{|S i|}{|S|} * \operatorname{Entrotpy}(S i)$

Keterangan:

$\mathrm{S}:$ himpunan kasus

A : atribut

$\mathrm{N}$ : jumlah partisi atribut $\mathrm{A}$ 
$|\mathrm{Si}|$ : jumlah kasus pada partisi ke-i

$|\mathrm{S}|$ : jumlah kasus dalam $\mathrm{S}$

Perhitungan nilai entropy dapat dilihat dalam persamaan berikut:

$$
\text { Entropy }(\mathrm{s})=\sum_{i=1}^{n}-p i * \log _{2} p i
$$

Keterangan:

$\mathrm{S}$ :himpunan kasus
A : Fitur
$\mathrm{n}:$ Jumlah
pi : proporsi dari Si terhadap S

\section{Pohon Keputusan (Decision Tree)}

Manfaat utama dari pemakaian pohon keputusan ialah kemampuannya untuk mem-break down tahapan pengambilan keputusan dari yang rinci menjadi lebih simple sehingga pengambil keputusan akan lebih menginterprestasikan solusi dari permasalahan. Pohon keputusan digunakan juga untuk mengeksplorasi data dan menemukan hubungan yang tersembunyi [19].

Pada pohon keputusan (decision tree) terdapat tiga jenis node, yaitu:

1. Root Node, merupakan node yang paling atas.

2. Internal Node, merupakan node percabangan.

3. Leaf Node atau Terminal Node, merupakan node akhir.

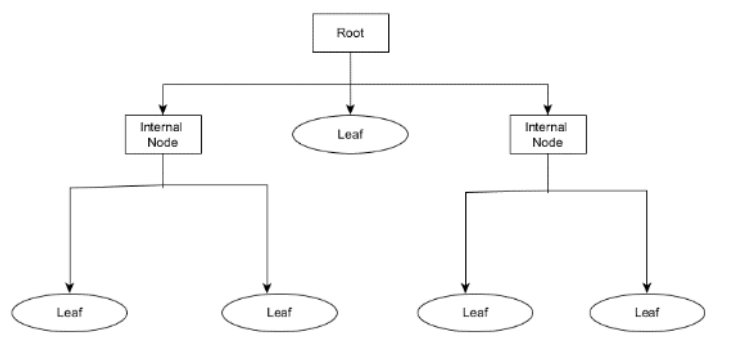

Gambar 1. Pohon keputusan

\section{Uji Validation}

Cross Validation ialah suatu teknik untuk memvalidasi atau menilai akurasi suatu model yang dihasilkan melalui data set tertentu. Salah satu teknik cross validation yang sering digunakan yaitu $k$-fold cross validation. Dalam teknik $k$-fold cross dilakukan sejumlah K-kali ujicoba, di mana masing-masing uji coba tersebut menggunakan data pastisi ke-K sebagai data uji coba, di mana masing-masing uji coba tersebut menggunakan data partisi ke-K sebagai data uji dan sisa partisi lainnya sebagai data latih. Untuk mengetahui nilai akurasi pada uji $k$-fold cross validation menggunakan persamaan berikut [20]:

$$
\text { Akurasi }=\frac{\text { Jumlah data benar }}{\text { Jumlah data uji }} \times 100 \%
$$

\section{HASIL DAN PEMBAHASAN}

\section{A. Analisa Data}

Setelah dianalisis, dataset tersebut memiliki 47 kasus hasil menghitung entropy dan nilai gain adalah sebagai berikut:

$$
\text { Entropy }(s)=\left(-\frac{29}{47} \times \log _{2}\left(\frac{29}{47}\right)\right)+\left(-\frac{18}{47} \times \log _{2}\left(\frac{18}{47}\right)\right)=0.9601
$$

TABEL I

HASIL PERHITUNGAN ENTROPY

\begin{tabular}{|c|c|c|c|c|}
\hline $\begin{array}{c}\text { Total } \\
\text { Data }\end{array}$ & Puas & Tidak Puas & Entropy & Gain \\
\hline 47 & 29 & 18 & 0.960118663 & \\
\hline
\end{tabular}

Setelah entropy total dihitung, maka tahapan selanjutnya adalah melalukan analisa dan perhitungan pada tiap-tiap atributnya. Selanjutnya melakukan pencarian nilai gain.

Gain Kualitas Produk $=0.960118663-\left(\left(\frac{2}{47} \times 0\right)+\right.$ $\left(\frac{21}{47} \times 0.276195428\right)+\left(\frac{15}{47} \times 0.996791632\right)+$ $\left.\left(\frac{9}{47} \times 0\right)+\left(\frac{0}{47} \times 0\right)\right)=0.518587206$

\begin{tabular}{|c|c|c|c|c|c|c|}
\hline Atribut & Nilai & $\begin{array}{c}\text { Jumlah } \\
\text { Kasus }\end{array}$ & Puas & $\begin{array}{l}\text { Tidak } \\
\text { Puas }\end{array}$ & Entropy & Gain \\
\hline \multirow{5}{*}{$\begin{array}{l}\text { Kualitas } \\
\text { Produk }\end{array}$} & $\begin{array}{l}\text { Sangat } \\
\text { Baik }\end{array}$ & 2 & 2 & 0 & 0 & \multirow{5}{*}{0.518587206} \\
\hline & Baik & 21 & 20 & 1 & 0.276195428 & \\
\hline & Cukup & 15 & 7 & 8 & 0.996791632 & \\
\hline & Kurang & 9 & 0 & 9 & 0 & \\
\hline & $\begin{array}{l}\text { Sangat } \\
\text { Kurang }\end{array}$ & 0 & 0 & 0 & 0 & \\
\hline \multirow{5}{*}{ Fasilitas } & $\begin{array}{l}\text { Sangat } \\
\text { Baik }\end{array}$ & 4 & 4 & 0 & $\mathbf{0}$ & \multirow{5}{*}{0.374311238} \\
\hline & Baik & 26 & 22 & 4 & 0.619382195 & \\
\hline & Cukup & 17 & 3 & 14 & 0.672294817 & \\
\hline & Kurang & 0 & 0 & 0 & 0 & \\
\hline & $\begin{array}{l}\text { Sangat } \\
\text { Kurang }\end{array}$ & 0 & 0 & 0 & 0 & \\
\hline Pelayanan & $\begin{array}{l}\text { Sangat } \\
\text { Baik }\end{array}$ & 6 & 5 & 1 & 0.650022422 & 0.380898396 \\
\hline
\end{tabular}

TABEL III

HASIL PERHITUNGAN TOTAL NODE 1 


\begin{tabular}{|c|c|c|c|c|c|c|}
\hline Atribut & Nilai & $\begin{array}{c}\text { Jumlah } \\
\text { Kasus }\end{array}$ & Puas & $\begin{array}{l}\text { Tidak } \\
\text { Puas }\end{array}$ & Entropy & Gain \\
\hline & Baik & 26 & 22 & 4 & 0.619382195 & \\
\hline & Cukup & 10 & 2 & 8 & 0.721928095 & \\
\hline & Kurang & 5 & 0 & 5 & 0 & \\
\hline & $\begin{array}{l}\text { Sangat } \\
\text { Kurang }\end{array}$ & 0 & 0 & 0 & 0 & \\
\hline \multirow{5}{*}{ Harga } & $\begin{array}{l}\text { Sangat } \\
\text { Baik }\end{array}$ & 4 & 4 & 0 & 0 & \multirow{5}{*}{0.287768938} \\
\hline & Baik & 17 & 15 & 2 & 0.522559375 & \\
\hline & Cukup & 23 & 10 & 13 & 0.987692509 & \\
\hline & Kurang & 3 & 0 & 3 & o & \\
\hline & $\begin{array}{l}\text { Sangat } \\
\text { Kurang }\end{array}$ & 0 & 0 & 0 & $\mathbf{0}$ & \\
\hline
\end{tabular}

Dilihat berlandaskan perhitungan dari table II atribut dengan nilai Gain tertinggi ialah Kualitas Produk dengan hasil 0.518587206. Pohon keputusan yang terbentuk pada pencarian Node 1 seperti gambar 2.

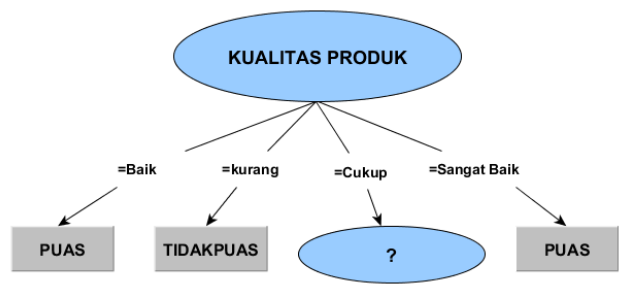

Gambar 2. Pohon keputusan node 1

Berikutnya melanjutkan perhitungan Node 1.1 yang menjadi akar pada pencarian. Seperti halnya perhitungan sebelumnya, yaitu dengan melakukan perhitungan nilai Entropy dari atribut yang masih ada yaitu Fasilitas, Pelayanan, dan Harga, setelah menghitung nilai Entropy, lalu nilai Gain setiap atribut dihitung 
TABEL IIIII

HASIL PERHITUNGAN NODE 1.2

\begin{tabular}{|c|c|c|c|c|c|c|}
\hline Atribut & Nilai & $\begin{array}{c}\text { Jumlah } \\
\text { Kasus }\end{array}$ & Puas & $\begin{array}{l}\text { Tidak } \\
\text { Puas }\end{array}$ & Entropy & Gain \\
\hline \multirow{5}{*}{ Fasilitas } & $\begin{array}{l}\text { Sangat } \\
\text { Baik }\end{array}$ & 4 & 4 & 0 & $\mathbf{0}$ & \multirow{5}{*}{0.084970565} \\
\hline & Baik & 26 & 22 & 4 & 0.619382195 & \\
\hline & Cukup & 17 & 3 & 14 & 0.672294817 & \\
\hline & Kurang & 0 & 0 & 0 & 0 & \\
\hline & $\begin{array}{l}\text { Sangat } \\
\text { Kurang }\end{array}$ & 0 & 0 & 0 & 0 & \\
\hline \multirow{5}{*}{ Pelayanan } & $\begin{array}{l}\text { Sangat } \\
\text { Baik }\end{array}$ & 6 & 5 & 1 & 0.650022422 & \multirow{5}{*}{0.084970565} \\
\hline & Baik & 26 & 22 & 4 & 0.619382195 & \\
\hline & Cukup & 10 & 2 & 8 & 0.721928095 & \\
\hline & Kurang & 5 & 0 & 5 & o & \\
\hline & $\begin{array}{l}\text { Sangat } \\
\text { Kurang }\end{array}$ & 0 & 0 & 0 & $\mathbf{0}$ & \\
\hline \multirow{5}{*}{ Harga } & $\begin{array}{l}\text { Sangat } \\
\text { Baik }\end{array}$ & 4 & 4 & 0 & $\mathbf{0}$ & \multirow{5}{*}{0.000494507} \\
\hline & Baik & 17 & 15 & 2 & 0.522559375 & \\
\hline & Cukup & 23 & 10 & 13 & 0.987692509 & \\
\hline & Kurang & 3 & 0 & 3 & 0 & \\
\hline & $\begin{array}{l}\text { Sangat } \\
\text { Kurang }\end{array}$ & 0 & 0 & 0 & $\mathbf{0}$ & \\
\hline
\end{tabular}

Dilihat berlandaskan perhitungan dari table III atribut Fasilitas dan Pelayanan memiliki nilai Gain yang sama akan tetapi Fasilitas dikarnakan urutan pertama yaitu 0.084970565. Pohon keputusan yang terbentuk pada pencarian Node 1.2 seperti gambar 3 .

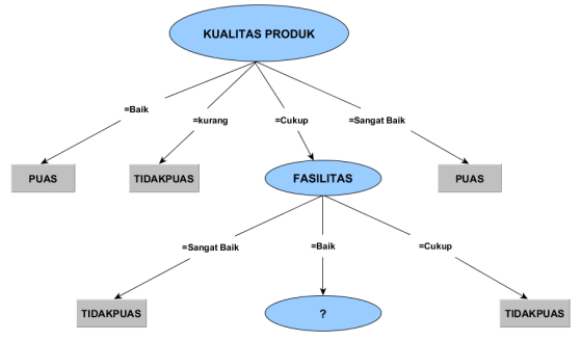

Gambar 3. Pohon keputusan Node 1.2
Node 1.2 sudah terbentuk pohon keputusannya, tahapan berikutnya melanjutkan perhitungan Node 1.3. Seperti halnya perhitungan sebelumnya, yaitu dengan melakukan perhitungan nilai Entropy dari atribut yang masih ada yaitu Pelayanan, dan Harga, setelah menghitung nilai Entropy, lalu nilai Gain setiap atribut dihitung.

TABEL IVV

HASIL PERHITUNGAN NODE 1.3

\begin{tabular}{|c|c|c|c|c|c|c|}
\hline Atribut & Nilai & $\begin{array}{c}\text { Jumlah } \\
\text { Kasus }\end{array}$ & Puas & $\begin{array}{c}\text { Tidak } \\
\text { Puas }\end{array}$ & Entropy & Gain \\
\hline \multirow{5}{*}{ Pelayanan } & $\begin{array}{c}\text { Sangat } \\
\text { Baik }\end{array}$ & 6 & 5 & 1 & 0.650022422 & \multirow{5}{*}{0.04635119} \\
\hline & Baik & 26 & 22 & 4 & 0.619382195 & \\
\hline & Cukup & 10 & 2 & 8 & 0.721928095 & \\
\hline & Kurang & 5 & 0 & 5 & $\mathbf{0}$ & \\
\hline & $\begin{array}{l}\text { Sangat } \\
\text { Kurang }\end{array}$ & 0 & 0 & 0 & $\mathbf{0}$ & \\
\hline \multirow{5}{*}{ Harga } & $\begin{array}{c}\text { Sangat } \\
\text { Baik }\end{array}$ & 4 & 4 & 0 & $\mathbf{0}$ & \multirow{5}{*}{-0.020157432} \\
\hline & Baik & 17 & 15 & 2 & 0.522559375 & \\
\hline & Cukup & 23 & 10 & 13 & 0.987692509 & \\
\hline & Kurang & 3 & 0 & 3 & 0 & \\
\hline & $\begin{array}{l}\text { Sangat } \\
\text { Kurang }\end{array}$ & 0 & 0 & 0 & $\mathbf{0}$ & \\
\hline
\end{tabular}


Dilihat berlandaskan perhitungan dari table IV atribut dengan nilai Gain tertinggi ialah Pelayanan yaitu 0.04635119. Pohon keputusan yang terbentuk pada pencarian Node 1.3 seperti gambar 4 .

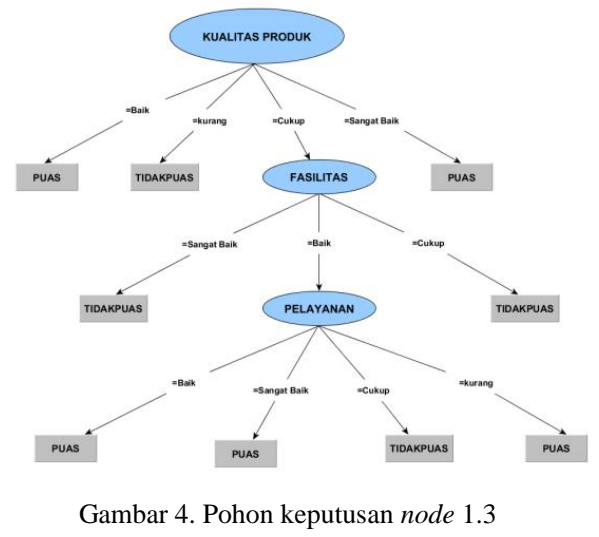

Berlandaskan pada perhitungan node 1.3 yang sudah tidak memiliki atribut akar maka perhitungan diselesaikan.

\section{B. Rule Hasil dari Perhitungan Entropy dan Gain}

Rule berlandaskan dari hasil pohon keputusan terakhir yang terbentuk melalui hasil dari perhitungan nilai entropy dan nilai gain. Dari pohon keputusan tersebut didapatkan 9 aturan(rule) sebagai prediksi tingkat kepuasan konsumen. 9 aturan(rule) tersebut ialah:

1. Jika Kualitas Produk Sangat Baik Maka Konsumen Merasa Puas

2. Jika Kualitas Produk Baik Maka Konsumen Merasa Puas

3. Jika Kualitas Produk Kurang Maka Konsumen Merasa Tidak Puas

4. Jika Kualitas Produk Cukup dan Fasilitas Sangat Baik Maka Merasa Konsumen Tidak Puas

5. Jika Kualitas Produk Cukup dan Fasilitas Cukup Maka Konsumen Merasa Tidak Puas

6. Jika Kualitas Produk Cukup dan Fasilitas Baik dan Pelayanan Sangat Baik Maka Konsumen Merasa Puas

7. Jika Kualitas Produk Cukup dan Fasilitas Baik dan Pelayanan Baik Maka Konsumen Merasa Puas

8. Jika Kualitas Produk Cukup dan Fasilitas Baik dan Pelayanan Kurang Maka Konsumen Merasa Puas

9. Jika Kualitas Produk Cukup dan Fasilitas Baik dan Pelayanan Cukup Maka Konsumen Merasa Tidak Puas.

C. Pengujian Menggunakan Software WEKA 3.8.3

Melakukan pengujian dari hasil analisa perlu diterapkan untuk memastikan hasil dari analisa tersebut sudah sesuai terhadap keputusan yang ditujukan. Implementasi dan pengujian dari penilitian ini memakai Software WEKA 3.8.3. Dengan pengujian data memakai software WEKA 3.8.3 peneliti hendak melakukan perbandingan dari hasil pengolahan data secara manual dengan memakai sebuah software atau perangkat dari sebuah aplikasi yang sudah ada. Hasil pohon keputusan menggunakan software WEKA seperti berikut ini:

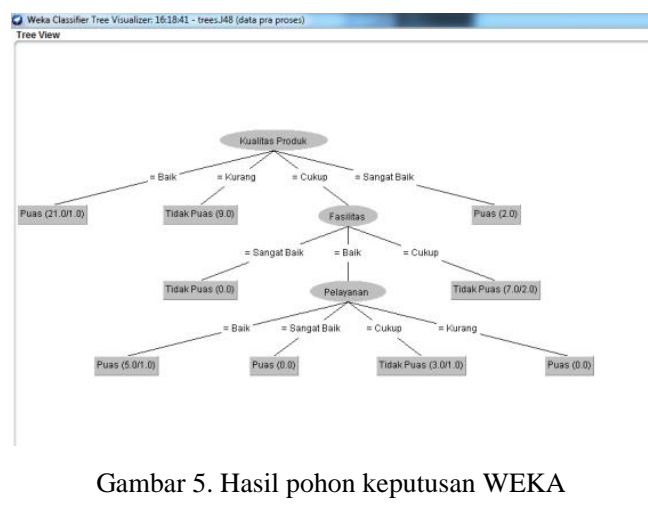

D. Rule Hasil Dari Pengujian

Berlandaskan pada hasil pohon keputusan WEKA, berikut aturan(rule) yang terbentuk:

1. Jika Kualitas Produk Sangat Baik Maka Konsumen Merasa Puas

2. Jika Kualitas Produk Baik Maka Konsumen Merasa Puas

3. Jika Kualitas Produk Kurang Maka Konsumen Merasa Tidak Puas

4. Jika Kualitas Produk Cukup dan Fasilitas Sangat Baik Maka Konsumen Merasa Tidak Puas

5. Jika Kualitas Produk Cukup dan Fasilitas Cukup Maka Konsumen Merasa Tidak Puas

6. Jika Kualitas Produk Cukup dan Fasilitas Baik dan Pelayanan Sangat Baik Maka Merasa Konsumen Puas

7. Jika Kualitas Produk Cukup dan Fasilitas Baik dan Pelayanan Baik Maka Merasa Konsumen Puas

8. Jika Kualitas Produk Cukup dan Fasilitas Baik dan Pelayanan Kurang Maka Merasa Konsumen Puas

9. Jika Kualitas Produk Cukup dan Fasilitas Baik dan Pelayanan Cukup Maka Merasa Konsumen Tidak Puas.

E. Uji Validation

Dari hasil uji cross validation untuk mengevaluasi kinerja model adalah sebagai berikut:

1) Nilai Correctly Classified Instance (CIC): dimana banyak baris data yang terklasifikasikan dengan benar adalah sebesar $78.7234 \%$

2) Nilai Incorrecty Classified Instance (ICI): dimana banyak baris data yang terklasifikasikan dengan salah adalah sebesar $21.2766 \%$

3) Hasil akurasi: yang didapatkan pada uji validasi menggunakan metode algoritma C4.5 yaitu $84.66 \%$, classification recall mendapatkan 0.828 , classification precision memperoleh 0.828 , dan ROC mendapat nilai 0.825 .

\section{KESIMPULAN}

Berdasarkan pembahasan dari decision tree penggunaan sinyal dari Base Transceiver Station (BTS) maka dapat diperoleh kesimpulan. Adapun kesimpulan-kesimpulan tersebut adalah sebagai berikut:

1. Data mining algoritma $\mathrm{C} 4.5$ dapat mengetahui tingkat kepuasan konsumen dari kuesioner yang diisi oleh konsumen. Terbukti dengan tingkat akurasi sebesar 
$84.66 \%$, recall mendapatkan 0.828 , precision memperoleh 0.828 , dan ROC mendapat nilai 0.825 .

2. Dari pohon keputusan yang terbentuk, variabel tertinggi pada kepuasan konsumen adalah variabel Kualitas Produk, artinya kualitas produk sangat berpengaruh terhadap tingkat kepuasan konsumen. Adapun Kualitas produk yang ditujukan dari kuesioner yaitu sinyal akses data yang masih berada pada tingkat kepuasan cukup.

\section{UCAPAN TERIMA KASIH}

Terima kasih dan penghargaan kepada LPPM Universitas Putera Batam yang telah membantu dalam fasilitas laboratorium dan pustaka hingga dapat terselesainya penelitian.

\section{DAFTAR PUSTAKA}

[1] E. V. Pogorelova, I. V. Yakhneeva, A. N. Agafonova, and A. O. Prokubovskaya, "Marketing mix for e-commerce," Int. J. Environ. Sci. Educ., vol. 11, no. 14, pp. 6744-6759, 2016.

[2] M. Ibrani, E. Hamiti, L. Ahma, R. Halili, and J. Dobruna, "Insitu experimental evaluation of LTE downlink signal levels in vicinity of base transceiver stations in urban area," 2017 IEEE Int. Black Sea Conf. Commun. Networking, BlackSeaCom 2017, vol. 2018-January, no. December 2009, pp. 1-5, 2018.

[3] A. Musa and B. S. Paul, "Analysis of Solar and Fossil Fuel Powered Base Transceiver Stations," IEEE AFRICON Conf., vol. 2019-September, 2019.

[4] P. Nugroho, W. W. Winarno, and R. Hartanto, "Faktor-faktor yang mempengaruhi niat menggunakan mobile payment dengan pendekatan extended the unified theory of acceptance and use of technology," CITEE Dep. Tek. Elektro dan Teknol. Informasi, FT UGM, pp. 226-233, 2017.

[5] J. S. Ojo, P. A. Owolawi, and A. M. Atoye, "Designing a Green Power Delivery System for Base Transceiver Stations in Southwestern Nigeria," SAIEE Africa Res. J., vol. 110, no. 1, pp. $19-25,2019$

[6] T. Ramunenyiwa, K. Awodele, and O. S. Omogoye, "Development of a cost-effective solar-wind-fuel cell independent power plant for a remote base transceiver station," $2020 \quad$ Int. SAUPEC/RobMech/PRASA Conf. SAUPEC/RobMech/PRASA 2020, pp. 2-7, 2020.

[7] W. W. Wibowo, Y. D. R. W. Astuti, and C. Hudaya, "SolarPowered Base Transceiver Station," Proc. - 2018 2nd Int. Conf. Green Energy Appl. ICGEA 2018, pp. 108-112, 2018.

[8] S. K. Bhondge, D. B. Bhoyar, and S. Mohad, "Strategy for power consumption management at base transceiver station," IEEE WCTFTR 2016 - Proc. 2016 World Conf. Futur. Trends Res. Innov. Soc. Welf., 2016

[9] Y. Y. Tefera, T. Kibatu, B. S. Shawel, and D. H. Woldegebreal,
"Recurrent Neural Network-based Base Transceiver Station Power Supply System Failure Prediction," Proc. Int. Jt. Conf. Neural Networks, 2020

[10] S. Takalapeta, "Penerapan Data Mining Untuk Menganalisis Kepuasan Konsumen Menggunakan," J I M P - J. Inform. Merdeka Pasuruan, vol. 3, no. 3, pp. 34-38, 2018.

[11] M. M. Nareswari and A. P. S. T, "Analisis Kepuasan Pemakai Layanan WIFI.ID Pada WIFI.ID Corner Di Kota Bandung," $e$ Proceeding Manag., vol. 3, no. 2, pp. 1041-1046, 2016.

[12] F. N. dkk Zahrah, "Pengaruh Kualitas Produk, Kualitas Pelayanan, Dan Harga Terhadap Kepuasan Pelanggan Dalam Meningkatkan Loyalitas Pelanggan Indihome Di Kota Bandung," e-proceeding Manag., vol. 4, no. 3, pp. 2187-2194 2017.

[13] W. Insyroh and T. Setyowati, "Determinan Kualitas Pelayanan Harga dan Produk Terhadap Kepuasan Pelanggan Telkomsel Flash Di Bondowoso," Int. J. Soc. Sci. Bus., vol. 2, no. 3, pp. 132-140, 2018.

[14] A. Rangga and A. Nalendra, "Pengaruh Kualitas Pelayanan Harga Kepuasan Pelanggan Terhadap Loyalitas Pelanggan (Studi Kasus Pelanggan Im3 Madiun)," JITK, vol. 3, no. 2, pp. 281-288, 2018.

[15] S. Moha and S. Loindong, "The Analysis Of Service Quality On Customer Satisfaction And Facilities," J. EMBA, vol. 4, no. 1, pp. 575-584, 2017.

[16] B. C. Devi and A. Hoyyi, "Analisa faktor-faktor yang mempengaruhi keputusan pembelian dan kepuasan konsumen pada layanan internet speedy di kota semarang menggunakan partial least square (pls)," J. Gaussian, vol. 4, no. 3, pp. 485495, 2015.

[17] H. Santoso, I. P. Hariyadi, and Prayitno, "Data Mining Analisa Pola Pembelian Produk Dengan Menggunakan Metode Algoritma Apriori," Tek. Inform., no. 1, pp. 19-24, 2016.

[18] E. Elisa, "Market Basket Analysis Pada Mini Market Ayu Dengan Algoritma Apriori," J. RESTI (Rekayasa Sist. dan Teknol. Informasi), vol. 2, no. 2, pp. 472-478, 2018.

[19] S. Faisal, "Klasifikasi data minning menggunakan algoritma c4.5 terhadap kepuasan pelanggan sewa kamera cikarang," Techno Xplore J. Ilmu Komput. dan Teknol. Inf., vol. 4, no. April, pp. 1-8, 2019.

[20] U. Febriana, M. T. Furqon, and B. Rahayudi, "Klasifikasi Penyakit Typhoid Fever ( TF ) dan Dengue Haemorhagic Fever ( DHF ) dengan Menerapkan Algoritma Decision Tree C4 . 5 ( Studi Kasus : Rumah Sakit Wilujeng Kediri ),” J. Pengemb. Teknol. Inf. dan Ilmu Komput., vol. 2, no. 3, pp. 1275-1282, 2018. 